\title{
ON THE METAMORPHOSIS OF THE VISUAL PIGMENTS OF ANGUILLA ANGUILLA (L.)
}

\author{
By D. B. Carlisle and E. J. Denton
}

The Plymouth Laboratory

(Text-fig. I)

The retinae of all the species of deep-sea fish which have been studied have been shown to contain golden coloured pigments, chrysopsins, which are especially suited to the light found in their natural environment (Denton \& Warren, 1957; Munz, 1958). Amongst fish caught in shallow coastal waters this characteristic colour of retinal pigment is found only in the conger eel Conger conger (by Denton \& Walker, 1958), and amongst freshwater fish only in the silver eel Anguilla anguilla (by Carlisle \& Denton, 1957, referred to by Denton \& Warren, 1957). Both these fish are species of Apodes, a group of which the vast majority of species are deep-water forms. Both species, moreover, begin their life in the deep sea and return to it again when mature to spawn and may therefore, in one sense, be regarded as deep-sea fish. Since immature conger eels in shallow coastal waters already have a retinal pigment characteristic of a deep-sea fish, it seems very unlikely that on returning to deep water they would change away from the deep-sea form which they already possess. It is probable therefore that the conger retains a deep-sea form of retinal pigment throughout the whole of its life.

There remained, on beginning these experiments, a curious difference between the silver form of the European eel, $A$. anguilla, with its golden coloured retina, and the North American eel, A. rostrata, which had been shown to have a reddish purple retina believed to contain a mixture of rhodopsin and porphyropsin (Wald, 1945). It appeared then that either there was a difference between these two species of the genus Anguilla, or that there was a change of pigments during the life of the freshwater eel similar to that known to take place when the tadpole of the bullfrog becomes adult (Wald, r945).

The larva of $A$. anguilla is a leptocephalus, which metamorphoses to a juvenile elver as it approaches the coasts of Europe. The juvenile eel spends some years in the estuaries and rivers of Europe, where it is known as the yellow eel; a second metamorphosis then begins during which the eel assumes a silvery dress and the gonads begin to grow; this silver eel then migrates towards the deep Atlantic spawning grounds. This change of livery once begun can be hastened by injections of gonadotrophic hormones. Associated with the change in livery is an enlargement of the eye. D'Ancona (I927, 
I929) and Ferriani (1954) have studied this increase in the size of the eye and have shown that the diameter is doubled and the retinal area increases fourfold. D'Ancona states that despite this increase in area the number of rods in the retina remains constant. From this Bertin (1951; English edition, 1956) argues that as the eye enlarges the retina '.... must be less and less capable of light perception and that, on the whole, the enlargement of the eye constitutes degeneration rather than improvement' (English edition, 1956, p. 96).

We therefore posed ourselves two questions:

(I) Is there a change of retinal pigment at the change of livery in $A$. anguilla?

(2) Is the enlargement of the eye at this change of livery accompanied by any decrease in efficiency of the eye in absorbing light?

\section{MATERIAL AND METHODS}

The eels were all caught in fresh water; the deep-sea eel was caught in an Agassiz trawl and its retina was studied at sea aboard R.V. 'Sarsia'.

The retinae, from the eyes of eels which had previously been dark adapted for 2 days, were dissected out under a dim red light, mounted in a small chamber on a microscope slide in Ringer solution (Denton \& Wyllie, 1955), and studied whilst fresh.

The spectral absorption of light by the retina was measured by methods described in detail by Denton \& Walker (1958). Using one method (Method III of Denton \& Walker) the total optical density ${ }^{1}$ of the retina relative to an equal thickness of Ringer solution is determined as a function of wavelength; using another method (Method II of Denton \& Walker) the difference in density between unbleached retina and the same retina after bleaching with strong white light is determined as a function of wavelength.

In addition to the normal yellow and silver eels eight of the latter which had been injected with gonadotrophins to advance the degree of sexual maturity were used. Each of these animals was injected weekly for 4 weeks with 500 international units of human chorionic gonadotrophin and the same amount of mare serum gonadotrophin. Of these animals one of the males reached sexual maturity, while the females all showed enlarged ovaries and ova up to $400 \mu$ diameter. The eyes were further enlarged, but the retinae showed no significant differences from the normal silver eels and will not be considered further.

For histological purposes excised eyes were injected with Zenker's fixative and then fixed whole in this fluid, embedded in celloidin, sectioned and stained with Heidenhain's iron haematoxylin and van Gieson's stain.

1 The densities referred to in this communication are all optical densities:

$$
\log _{10}\left(\frac{\text { light incident }}{\text { light transmitted }}\right) \text {. }
$$




\section{RESULTS}

Several retinae of silver and yellow eels were dissected in quick succession and examined side by side in white light; the silver eel's retinae were golden in colour whilst those of the yellow eel were purple coloured. The density of pigment was seen to be at least as high if not higher in the silver eels than in the yellow eels. These simple observations confirmed observations made a year earlier on the silver eel and showed that there was a metamorphosis of the fresh water eel's visual pigments. Fig. I A shows that on metamorphosis of the visual pigment there is a shift in the maximum of the retinal difference curve of about $33 \mathrm{~m} \mu$ and Fig. 2 B shows that the mature silver eel has a curve of total retinal density very close to that of the conger eel. The metamorphosis is accompanied by an increase in retinal density. The maximum retinal density changes on bleaching two specimens of yellow eel were 0.34 and 0.21 , whilst the corresponding changes for the silver eel were 0.58 and 0.52 .

A specimen of a deep-sea eel Synaphobranchus sp. caught in an Agassiz trawl at a depth of about $800 \mathrm{~m}$ off the north coast of Spain gave a total retinal density curve very close to those of the conger eel and the silver freshwater eels.

The change in the eye as the eel changes from yellow to silver livery is well marked. In a specimen of yellow eel $6 \mathrm{I} \mathrm{cm}$ long the longest diameter of the eyeball was $3.3 \mathrm{~mm}$ while in a silver eel of the same length which had been injected with gonadotrophins this diameter was $7 \cdot 8 \mathrm{~mm}$. The relative thickness of the various layers of the retina was slightly altered, but we have not sectioned enough specimens to be certain that this change is constant. Most layers are thinner in the silver eel. The number of rods in a median section of these two retinae is approximately the same. They are no wider spaced in the silver eel, however, for the external segments of the rods are about twice the diameter of the rods in the yellow eel ( $3 \mu$ and $\mathrm{r} \cdot 5 \mu$ respectively). This enlargement in the rods seems adequate to account for the greater area of the retina. The rods are not increased significantly in length but we cannot find that they become shorter, as implied by D'Ancona (1927), who states that all the layers of the retina become distinctly thinner, though this is least marked in the layer of rods. (' I vari strati retinici sono distintamente assottigliati. Tale fatto è invece meno accentuato nello strato dei bastoncelli.') In comparable regions of the retina the thicknesses of the rod layer, measured from the external limiting membrane to the pigmented layer, were $92 \mu$ in a silver eel and $86 \mu$ in a yellow eel at the thickest part.

\section{DISCUSSION}

During the metamorphosis from the immature yellow to the mature silver form there are extensive changes equipping the eel for its deep-sea environment. These results show that these changes include one in which the retinal 
pigment becomes similar to those of the deep-sea fish. This takes place even before the fish leaves fresh water. The change is analogous to that described I4 years ago in the bullfrog (Wald, I945), and to the change in retinal pigments recently shown to take place in the lamprey (Wald, I957). Wald, Brown $\&$ Brown (private communication) have now investigated the chemistry of the metamorphosis of the visual pigment in the freshwater eel and have not only confirmed these results but have elucidated in detail both the nature and
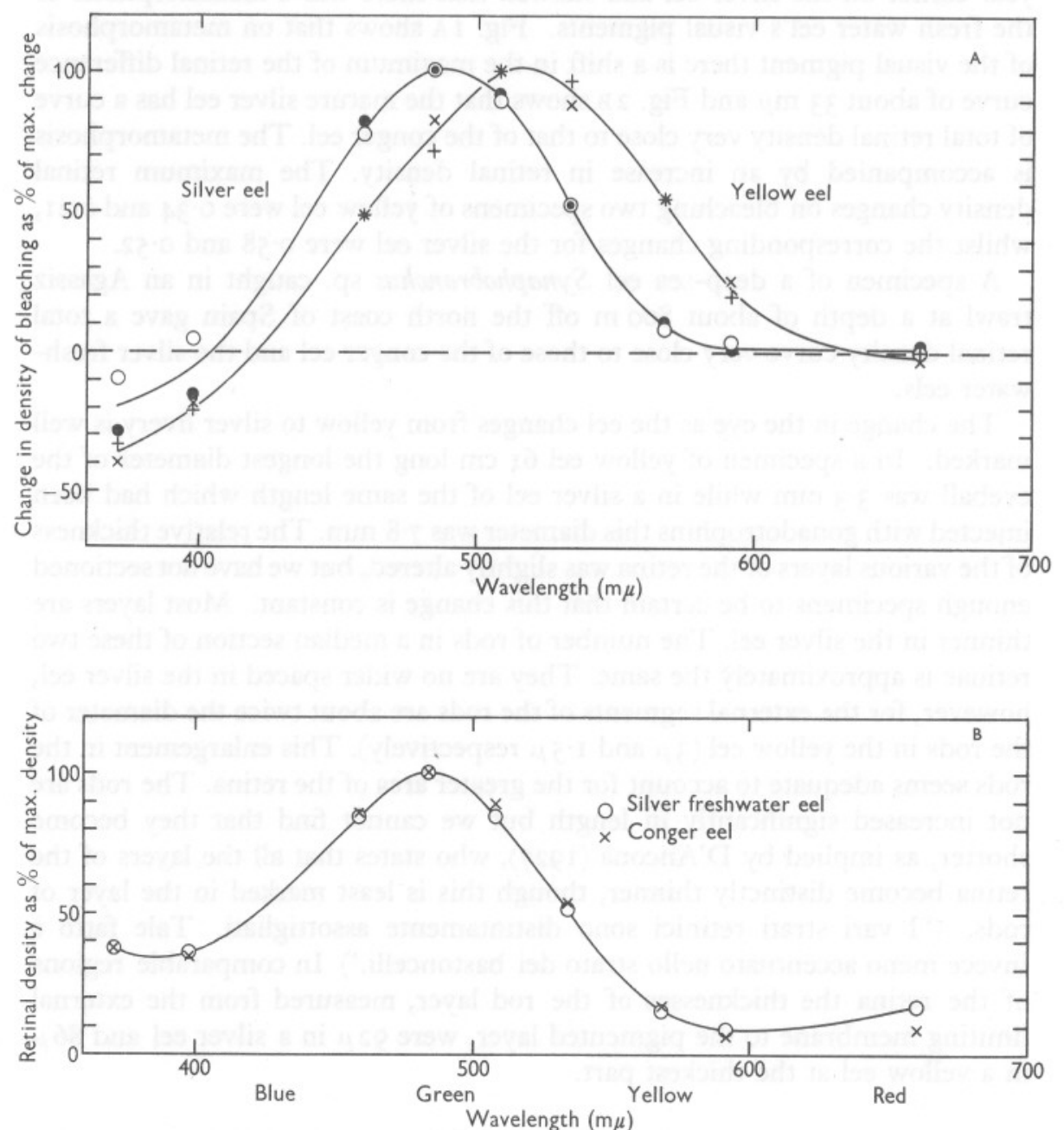

Fig. I. A, Anguilla anguilla: immature (yellow) eels and mature (silver) eels. Spectral curves of difference in density between unbleached dark adapted retinae and the same retinae an hour after bleaching their photosensitive pigments with strong white light. B, Conger conger and mature (silver) eels (Anguilla anguilla). Spectral curves of densities of unbleached retinae with respect to an equal thickness of Ringer's solution. 
course of this metamorphosis. Their results and those obtained here are in good accord.

Whilst the observations of D'Ancona on the histology of the eyes of yellow and silver eels are confirmed here, the deductions made from D'Ancona's observations by Bertin would seem to be false. The fraction of light incident on the retina absorbed by the retinal pigments is very high in the silver eel; after taking account of the shift in absorption curve the eye of the silver eel is more efficient than that of the yellow eel in usefully absorbing light striking the retina.

Despite the great change in calcium metabolism there is no change in the absorption of light by the crystalline lens on metamorphosis (Denton, E. J. \& Warren, F. J. unpublished observation), but in size the lens and the pupil increase even more than does the eye itself.

For a silver and a yellow eel looking at the same small source of light at the same distance, the total light thrown on to the silver eel's retina will be greater (because of the absolutely larger pupil), the brightness of the silver eel's retinal image will be greater (because of the relatively larger pupil), and the fraction of light absorbed by the retinal photosensitive pigments will be greater (because of the higher retinal density of pigment).

We are very grateful to Mr A. C. G. Best for making the histological preparations for us.

We are indebted to the Royal Society for a scientific grant-in-aid, and to Organon Laboratories Limited for a gift of gonadotrophic hormones.

\section{SUMMARY}

European eels, Anguilla anguilla (L), while they retain the immature 'yellow' livery, have purplish coloured retinae, close in colour to those of freshwater fish. The purple colour is that of photosensitive pigments.

When an eel assumes the 'silver' livery of approaching maturity, in preparation for the deep-sea transatlantic migration to the breeding grounds off the Bermudas, the eye enlarges and the retina changes to a golden colour, like that of the photosensitive chrysopsins of deep-sea fish. The maximum of absorption shifts by about $33 \mathrm{~m} \mu$ towards the shorter wavelength end of the spectrum and the final total retinal density curve of the silver eel is almost identical with that of the conger eel, Conger conger (L), and of a deep-sea eel, Synaphobranchus $\mathrm{sp}$. This change of pigment takes place even before the fish leaves fresh water.

The larger eye and the relatively even larger pupil of the silver eel make it a more efficient light-collecting organ, whilst the total retinal density of photosensitive pigment is higher in the silver than the yellow eel and the retina will therefore be more efficient in usefully absorbing the light incident on it. 


\section{REFERENCES}

Bertin, L., 195I. Les Anguilles. Paris.

- 1956. Eels. London.

Carlisle, D. B. \& Denton, E. J., 1957. A change in visual pigments in the life of the fresh water eel. F. Physiol., Vol. 139, p. 8P.

D'ANCONA, U., 1927. Richerche sull'ingrandimento dell'occhio dell'anguilla in rapporto alla maturità sessuale e considerazioni sul suo significata biologico. R.C. Accad. Lincei, Vol. 5, Ser. 6, pp. 360-3.

- 1929. Sui fenomeni di circolazione che accompagnano l'ingrandimento dell'occhio nella maturità sessuale dell'Anguilla. Boll. Soc. eustach., Anno 27 (I-2), No. 7 , pp. I-8.

Denton, E. J. \& Walker, Mary AnN, 1958. The visual pigment of the conger eel. Proc. roy Soc. B, Vol. I48, pp. 257-69.

DENTON, E. J. \& WARREN, F. J., I957. The photosensitive pigments in the retinae of deep sea fish. F. mar. biol. Ass. U.K., Vol. 36, pp. 65I-62.

Denton, E. J. \& Wyllie, J. H., 1955. Study of the photosensitive pigments in the pink and green rods of the frog. F. Physiol. Vol. 127, pp. 81-9.

FERIANI, M., I954. Variazioni morfologici e funzionali dell'occhio dell'Anguilla nell'acquisizione dell'abito riproduttivo. Boll. Zool. Vol. 2I, pp. 40I-4.

MunZ, F. W. 1958. Photosensitive pigments from retinae of certain deep-sea fishes. F. Physiol., Vol. 140, pp. 220-35.

WALD, G., I945. The chemical evolution of vision. Harvey Lect., Vol. 4I, pp. II7-60. 1957. The metamorphosis of the visual systems in the sea lamprey. F. gen. Physiol., Vol. 40, pp. 90I-I4. 